\title{
PENGARUH ELEMEN PENANDA PADA PENGENALAN IDENTITAS TAMAN JEPANG
}

Studi Eksperimen terhadap Pengenalan Identitas Taman Jepang oleh Pengamat dari Indonesia

Artbanu Wishnu Aji* Program Studi Desain Interior, Fakultas Seni Rupa, Institut Seni Indonesia Yogyakarta

\begin{abstract}
Japanese garden is one of the finest gardens in the world. Its beauty has been recognized in many countries outside Japan. Although it is difficult to be created in tropical climate such as in Indonesia, many Indonesian would like to have Japanese garden in their home. This Research investigated the possibility to create Japanese garden with less element in tropical environment without losing its identity. Two initial exploration studies were conducted in Kyoto and Indonesia. Fourteen traditional gardens were chosen to be explored in the first exploration study. Its aim was to understand material and composition variation of each element in the original setting. The second one was carried out in Indonesia to find out the image of Japanese garden in the expert's point of view. The findings of these studies were used to design ten series of pictures. Each picture contained one element of the garden which can be rated in semantic differential scale from weak to strong by 120 respondents. Lantern, gate, trees, stone and water basin were rated as strong element whilst fence, pond, waterfall, stone path and bridge were rated as weak elements. Five strong elements were grouped into one garden composition as well as the weak ones. The garden composition picture was presented to 200 respondents in two separate groups. Each group consists of 100 respondents with one stimulus picture only. A t-test was used to analyze the mean difference of two groups. The result shows a significant difference in respondent's ability to recognize Japanese garden identity between group with strong garden elements and with the weak ones.
\end{abstract}

Keywords: Japanese garden, garden elements, Identity

Taman Jepang merupakan salah satu kekayaan budaya Jepang yang telah dikenal di berbagai Negara, termasuk Indonesia. Keberadaan taman Jepang di negara-negara seperti Amerika Serikat, Kanada dan berbagai negara Eropa menunjukkan gaya taman Jepang dapat diterima sebagai alternatif desain bagi masyarakat di luar Jepang. Keberadaan taman Jepang di Amerika, Kanada dan Eropa sebagian merupakan hadiah dari pemerintah Jepang kepada masyarakat di belahan benua tersebut. Hadiah ini dimaksudkan untuk memperkenalkan budaya Jepang kepada masyarakat dunia sehingga taman-taman ini berbentuk ruang publik yang dapat di akses oleh seluruh lapisan masyarakat.

Masyarakat Indonesia juga menggemari gaya desain taman Jepang untuk taman halaman rumah maupun di dalam rumah. Hal ini terlihat dari munculnya elemen-elemen taman Jepang dalam komposisi taman bergaya tropis. Elemen taman Jepang yang sering diterapkan dalam desain taman di Indonesia adalah pemakaian komposisi batu, bentuk semak-semak bundar, jembatan mini, lentera dan jalan setapak. Pemakaian elemen-elemen tersebut menunjukkan bahwa desain taman bergaya Jepang diminati oleh masyarakat Indonesia.

Keterkaitan antara iklim empat musim dengan desain taman membuat taman Jepang sulit untuk dikembangkan di daerah

${ }^{*}$ Korespondensi penulis dialamatkan ke Program Studi Desain Interior, Fakultas Seni Rupa, Institut Seni Indonesia Yogyakarta, Tel/Fax: +62 274417219 e-mail: banu_art@yahoo.com 
tropis seperti Indonesia. Tumbuhan pengisi taman yang biasa dijumpai di taman Jepang seperti Maple Jepang ( Acer Palmatum ) tidak mungkin berubah warna menjadi merah di iklim tropis. Warna merah daun Maple Jepang telah menjadi ciri khas taman Jepang di musim gugur dan menjadi daya tarik tersendiri bagi pengamatnya.

Atsmosfer taman Jepang yang berubah setiap musim juga tidak dapat diterapkan pada iklim tropis Indonesia. Keterbatasan ini membuat desain taman Jepang di daerah tropis hanya terbatas pada peniruan gaya ( Japanesque). Peniruan gaya taman Jepang telah banyak dilakukan di Indonesia. Contoh peniruan gaya ini terlihat dalam taman-taman di halaman rumah yang biasanya memakai elemen artifiasial untuk menggantikan material aslinya.

Iklim tropis Indonesia disatu sisi menjadi penghambat bagi penciptaan taman Jepang yang sempurna, akan tetapi disisi lain desain tiruan taman Jepang ini digemari pula oleh masyarakat Indonesia dan menjadi salah satu alternatif bagi desain taman di Indonesia.

Taman-taman bergaya campuran Jepang dan taman tropis dapat dengan mudah dijumpai di sudut-sudut kota besar seperti Jakarta dan Yogyakarta. Seiring dengan giatnya pemerintah kota untuk memperindah lingkungan perkotaan maka pembuatan taman menjadi salah satu alternatif pemecahannya.

Desain taman Jepang dengan nilai estetikanya yang tinggi dapat pula dijadikan pilihan desain dalam upaya mengisi ruangruang kota di Indonesia. Keane (1996) menegaskan bahwa taman Jepang pada dasarnya adalah karya seni urban yang muncul seiring dengan kebutuhan masyarakat kota untuk memperindah lingkungan disekitar mereka dan mengurangi stress di perkotaan.

Permasalahan yang timbul di Indonesia untuk menciptakan taman Jepang adalah langkanya material pendukung dan perbedaan iklim kedua negara. Desain taman Jepang yang lengkap dengan semua elemennya tidak mungkin dilakukan di Indonesia sehingga perlu dilakukan pemilihan elemen yang tersedia dan memiliki identitas yang kuat. Hal ini dimaksudkan untuk mengurangi elemen taman namun tetap mempertahankan identitas taman Jepang.

Upaya untuk menciptakan taman Jepang dengan citra dan identitas Jepang yang mendekati aslinya perlu dilakukan untuk menghindari kombinasi gaya yang merusak komposisi taman secara keseluruhan. Penelitian ini dimaksudkan untuk mengungkapkan beberapa hal yang dapat dirumuskan dalam dua pertanyaan penelitian ,yaitu elemen-elemen apa sajakah dalam taman Jepang yang memiliki asosiasi kuat dan lemah terhadap identitas taman Jepang oleh pengamat dari Indonesia dan apakah elemen-elemen kuat dan elemen-elemen lemah memiliki perbedaan signifikan pada pengenalan identitas taman Jepang oleh pengamat dari Indonesia

Penelitian ini memiliki dua tujuan,yaitu mengidentifikasi elemen-elemen taman Jepang yang memiliki asosiasi kuat dan lemah terhadap identitas taman Jepang , dan menemukan pengaruh elemen-elemen tersebut terhadap pengenalan identitas taman Jepang.

Terdapat dua manfaat dari penelitian ini yaitu manfaat teoritis dan manfaat praktis. Manfaat teoritis penelitian ini adalah menambah pengetahuan teoritis mengenai taman Jepang khususnya yang berkaitan dengan elemen desain dan prisip desain. Sedangkan manfaat praktis dari penelitian ini adalah memberikan pengetahuan bagi para praktisi yang berkecimpung dalam desain pertamanan dan landscape tentang elemen desain yang berperan dalam pembentukan identitas taman Jepang. Melalui pengetahuan ini desainer akan lebih mudah membuat desain taman Jepang meskipun tidak menggunakan seluruh elemennya.

\section{Jenis Taman Jepang}

Meskipun secara umum taman Jepang terlihat sama, masing-masing taman memiliki penekanan berbeda. Bring dan Wayamberg (1981) mengkategorikan taman Jepang menjadi tiga kategori yaitu :

Taman surgawi dikembangkan pada masa periode Heian dimana para bangsawan kekaisaran meniru taman-taman Cina yang memiliki kolam luas untuk berperahu. Taman jenis ini merupakan taman untuk menikmati acara seni dan hiburan seperti pembacaan puisi, tarian dan perlombaan tradisional. Bring 
dan Wayamberg (1981) menjelaskan bahwa taman surgawi merupakan fase pertama dari perkembangan taman Jepang yang biaanya dibangun di bagian selatan rumah-rumah bangsawan. Rumah bangsawan ini berbentuk $U$ dengan dua koridor yang mengapit halaman belakang. Ujung-ujung koridor tersebut dibangun pavilion yang berfungsi sebagai tempat untuk menikmati pertunjukan seni.

Taman Zen merupakan fase kedua dari perkembangan taman Jepang. Ciri utama taman ini adalah pemakaian elemen-elemen pasir, batu dan sedikit tanaman ( Bring dan Wayamberg, 1981). Elemen-elemen tersebut merupakan simbol atau abstraksi dari bentukbentuk lansekap seperti gunung, danau dan laut. Taman Zen memiliki komposisi sederhana yang dipengaruhi oleh lukisanlukisan lansekap dinansti Sung.

Taman Jamuan Teh. Taman teh dalam bahasa Jepang disebut sebagai Rojiniwa yang secara harafiah berarti "taman jalan setapak". Jalan setapak merupakan ciri utama dari taman teh selain dari gubug teh yang biasanya terletak ditengah taman. Gubug ini menurut Pile (1995) merupakan tempat untuk menghormati tamu undangan. Interior gubug ini sangat sederhana, di dalamnya hanya terdapat tungku dan alas duduk tanpa perabot lainnya.

Keane (1996) menambahkan satu kategori jenis taman yang biasanya dibangun di halaman belakang rumah tradisional. Taman ini disebut Tsubo Niwa (courtyard) atau taman halaman. Dibandingkan dengan ketiga jenis taman diatas Tsubo Niwa memiliki keluasan lebih kecil dan sedikit elemen.

\section{Persepsi Lingkungan}

Proses persepsi lingkungan menurut Veitch dan Arkkelin (1995) melibatkan empat hal dalam tahapannya, yaitu mendeteksi stimulus, mengenali stimulus, membedakan stimulus dan menilai tingkatan stimulus.

Mendeteksi stimulus adalah mengenali kehadiran stimulus disekitar kita, proses ini menurut Veitch dan Arkkelin (1995) merupakan perangkat survival bagi organisme. Lewat proses deteksi ini manusia bisa mengetahui perubahan energi seperti cahaya, suara atau perubahan kimiawi lingkungan. Manusia memiliki ambang tertentu untuk dapat mendeteksi kehadiran stimulus, sehingga apabila ambang ini terlalu rendah atau terlalu tinggi kehadirannya tidak dapat diketahui.

Rapoport (1982) menjelaskan bahwa dalam mengamati lingkungannya manusia bertumpu pada penanda-penanda (cues) lingkungan untuk bisa mengenali dan memprosesnya dalam otak. Proses ini terbagi dalam dua bagian yaitu tahap persepsi bentuk formal yang berupa garis,bidang dan warna dan persepsi psikososial yang meliputi tahap interpertasi serta asosiatif.

Persepsi lingkungan dengan demikian selalu melibatkan elemen lingkungan tertentu yang dipilih dan diproses dalam otak untuk. Elemen lingkungan ini berubah menjadi informasi-informasi yang dideteksi, dikenali dibedakan dan dinilai di dalam otak sehingga manusia mampu memberikan respon yang sesuai dengan kondisi lingkungan tersebut.

Jika berbicara tentang persepsi lingkungan maka perlu dibahas pula identitas lingkungan itu sendiri. Menurut Kamus Oxford identitas berarti sekumpulan aspek karakteristik yang memungkinkan sesuatu untuk dapat dikenali dengan jelas. Identitas juga memiliki akar kata latin idem yang berarti "sama". Identitas lingkungan dengan demikian dapat diartikan sebagai sekumpulan aspek karakteristik dalam satu lingkungan yang memungkinkan lingkungan tersebut untuk dikenali oleh pengamat.

Lynch dalam Sanoff (1991) menjelaskan bahwa identitas lingkungan berhubungan dengan kemampuan seseorang untuk mengenali ciri-ciri lingkungan. Ciri-ciri lingkungan ini memiliki asosiasi yang dapat dihubungan dengan lingkungan tersebut sehingga pengamat dapat mengenalinya kembali.

Sanoff (1991) menambahkan bahwa manusia mencerap lingkungan melalui indra setelah menangkap stimulus dari lingkungan itu. Stimulus ini berubah menjadi serangkaian informasi di dalam otak sehingga manusia dapat merespon balik. Respon ini berupa serangkaian perilaku untuk bertindak dan berperilaku sesuai dengan kondisinya.

Manusia dalam mengamati lingkungannya selalu berupaya untuk menemukan karakter terpenting lingkungan 
LINTAS

RUNANG | VOL.1 | EDISI 1 | 2007

dan menyimpannya dalam ingatan sebagai penanda. (Bell dan kawan-kawan, 1996). Tidak semua elemen lingkungan memiliki karakter khusus yang mudah dikenali, lingkungan tertentu kadang menjadi terlalu umum untuk dapat dikenali secara tepat. Hanya lingkungan dengan ciri khusus yang menonjol yang menyebabkan pengamat mengingat tempat tersebut dan mengenalinya kembali sebagai karakter suatu lingkungan.

Proses persepsi manusia terhadap lingkungan menurut Rapoport (1982) terbagi menjadi dua tahap, yaitu pengenalan bentukbentuk lingkungan yang meliputi garis, bidang dan warna serta tahap psikososial yang lebih komplek. Tahap psikososial ini merupakan tahap dimana manusia mulai menyeleksi elemen lingkungan yang memiliki karakteristik tertentu dan megasosiasikan dengan suatu identitas dan status.

Lingkungan buatan selalu mentransmisikan pesan kepada pengamat sehingga mereka dapat mengenali dan bertindak sesuai dengan lingkungannya. Rapoport (1982) menambahkan bahwa sistem sosial yang menentukan tindakan tertentu pada setting tertentu akan tetapi elemen lingkunganlah yang menuntun pengamat untuk dapat mengenali setting tersebut.

Sekali saja elemen lingkungan itu dikenali dan diasosiasikan dengan satu identitas maka hubungannya akan tetap stabil, artinya ketika ditempat lain di jumpai elemen lain yang serupa maka identitasnya akan tetap melekat.

\section{BAHAN DAN METODE}

Penelitian ini menggunakan dua variabel yaitu variabel bebas dan variabel tergantung. Variabel bebas adalah variabel yang diubah-ubah sehingga dapat diketahui pengaruhnya dalam variabel tergantung. Pengaruh ini diketahui dengan menggunakan pengukuran terhadap variabel tergantung. Kedua variabel dalam penelitian ini adalah: elemen penanda taman Jepang sebagai variable bebas dan tingkat pengenalan identitas terhadap taman Jepang sebagai variable tergantungnya.

Subjek dalam penelitian ini berjumlah 320 (tiga ratus dua puluh) orang yang terbagi dalam enam kelompok eksperimen. Enam kelompok ini terdiri dari tiga puluh mahasiswa desain interior ISI Yogyakarta, tiga puluh mahasiwa arsitektur UGM, tiga puluh

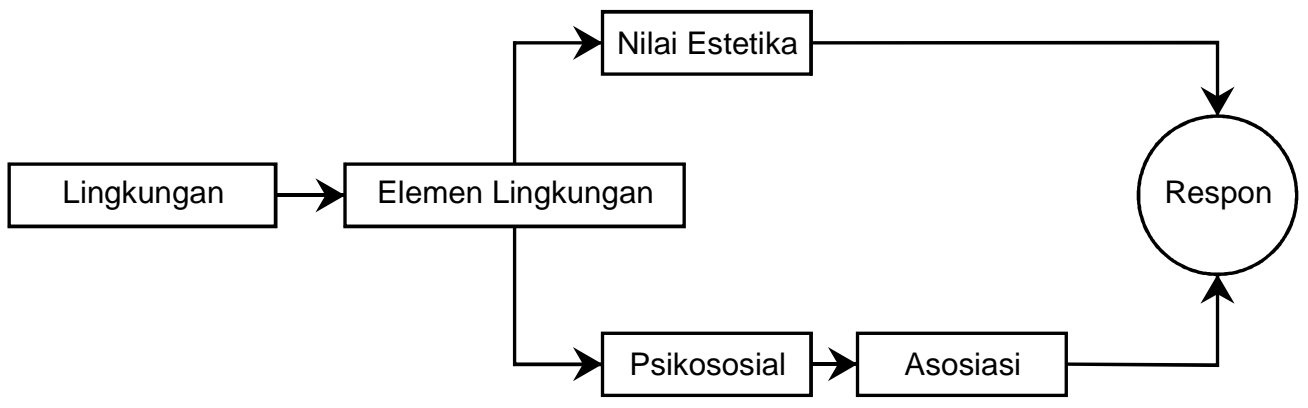

Gb.1. Diagram proses persepsi lingkungan oleh pengamat ( Dimodifikasi dari Rapoport,1982) 
mahasiswa kehutanan UGM, tiga puluh mahasiswa psikologi Sanata Dharma, seratus mahasiswa arsitektur UGM, seratus mahasiswa akademi teknik arsitektur YKPN

Empat kelompok pertama merupakan subjek penelitian untuk menentukan rating elemen, sehingga diperoleh dua kategori elemen yaitu kuat dan lemah. Dua kelompok terakhir adalah subjek yang digunakan untuk menentukan tingkat pengenalan identitas taman Jepang. Masingmasing subjek hanya menerima satu kali pengetesan.

Kelompok mahasiswa desain interior dan arsitektur dikelompokkan sebagai mahasiswa perencana, sedangkan mahasiswa kehutanan dan psikologi dikelompokkan sebagai mahasiwa pengamat. Hal ini dimaksudkan agar hasil rating empat kelompok ini mewakili dua kelompok yaitu kelompok desainer dan kelompok pengguna sehingga diperoleh hasil rating yang obyektif.

Elemen Penanda : Adalah elemen lingkungan yang memiliki karakter khusus seperti identitas lokal, penggunaan yang konsisten dan bentuk unik sehingga mudah dikenali. Elemen penanda ini kemudian diasosiasikan dengan budaya, identitas serta perilaku tertentu oleh pengamat. Elemen penanda taman Jepang dalam penelitian ini menggunakan kesepuluh elemen yang dikemukakan oleh Nyunt (1978). Kategori elemen penanda kuat dan lemah ditentukan dengan menggunakan angket.

Pengenalan Identitas Lingkungan : Tingkat kemampuan pengamat untuk mengenali jenis lingkungan apa yang dihadapinya. Pengenalan identitas lingkungan diukur dengan menggunakan angket yang berisi pertanyaan dari negara manakah gaya taman yang terlihat dalam gambar desain.

Penelitian ini adalah jenis penelitian eksperimen sehingga memerlukan rancangan penelitian. Menurut Conrad (1981) penelitian eksperimen adalah penelitian yang dilakukan dengan menggunakan variabel bebas terkontrol. Variabel bebas ini dapat diberikan dengan nilai nol dan satu atau dalam tingkatan yang berbeda seperti dua dan tiga.Bagan di bawah ini memperlihatkan tahapan penelitian dari mulai penentuan rating elemen hingga tahap pengambilan data untuk penelitian eksperimen

Penelitian awal terdiri dari dua tahap yaitu tahap pengambilan data untuk mengetahui variasi bahan dan desain taman Jepang serta tanggapan asosiatif pengamat dari Indonesia terhadap taman Jepang. Data variasi elemen dan bahan diambil dengan pengamatan langsung dilapangan sedangkan data tanggapan asosiatif ini diambil dengan menggunakan metoda wawancara dibantu dengan pedoman wawancara yang telah dipersiapkan

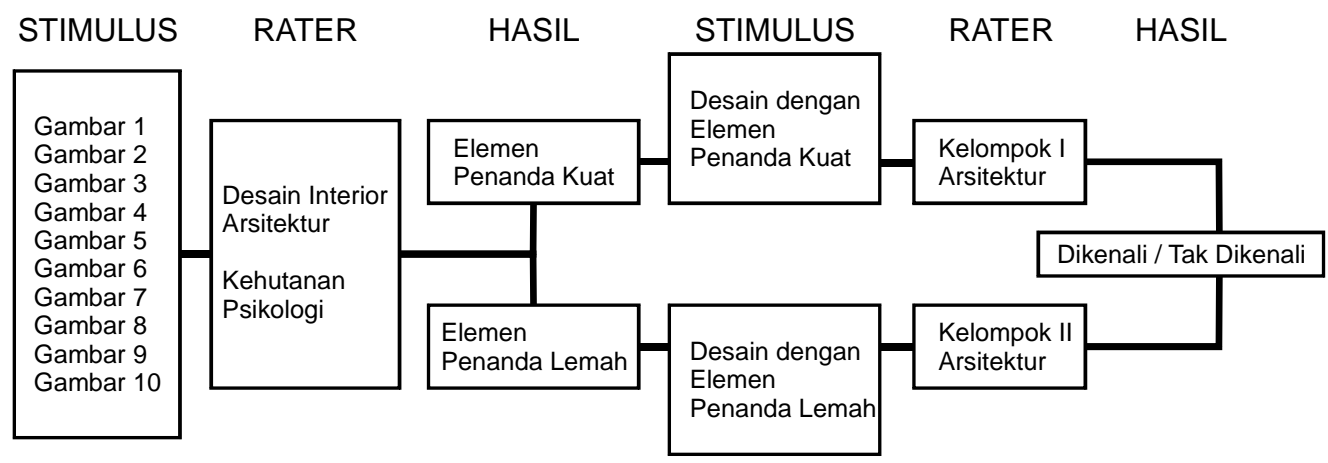

Gb.2. Bagan rancangan tahapan penelitian eksperimen 
sebelumnya.

Hasil wawancara dan penilaian tiap elemen desain ini digunakan sebagai pedoman untuk membuat alat ukur penelitian yang akan disajikan kepada subjek. Alat ukur ini berupa prototipe desain taman Jepang dengan menggunakan kesepuluh elemen penanda. Tingkat penegenalan Identitas lingkungan diukur dengan menggunakan pertanyaan seberapa kuat identitas yang terdapat pada setiap desain.

Analisis data awal diperlukan untuk menentukan asosiasi pengamat dari Indonesia terhadap taman Jepang. Analisis ini merupakan analisis kualitatif dengan mencari tema-tema yang sama dalam data hasil wawancara. Hasil wawancara mengenai elemen taman selanjutnya di analisis dengan mencari kata kunci yang menunjuk pada penggambaran apa yang dianggap memiliki identitas Jepang sehingga ditemukan konsep identitas taman Jepang menurut pengamat ahli dari Indonesia. Konsep ini digunakan sebagai dasar untuk membuat desain Jepang yang dipergunakan dalam fase penelitian utama. Penilaian hasil rating elemen yang diperoleh pada penelitian utama didasarkan pada skor gabungan keempat kelompok ( Desain interior, Arsitektur, Kehutanan dan Psikologi ) yang berjumlah 120 reseponden. Metode analisis yang dipakai dalam melihat perbedaan mean eksperimen kelompok subjek dengan stimulus elemen kuat dan elemen lemah adalah analisis Uji-t . Menurut Burns (2000) analisis ini digunakan untuk melihat perbedaan mean subjek yang mendapat dua macam perlakuan eksperimen secara terpisah (independent sample T-test) Perangkat lunak yang dipakai sebagai alat bantu untuk mengolah data dalam penelitian ini adalah SPSS. 11

Alat yang digunakan sebagai stimulus dalam penelitian eksperimen ini adalah sketsa desain taman Jepang. 
Fase eksploratori yang dilakukan di empat belas taman tradisional di Kyoto

menemukan berbagai macam material dan variasi desain, seperti tampak pada tabel 1 .

Tabel 1.Variasi Bahan dan Desain Taman Jepang

\begin{tabular}{|c|c|c|c|}
\hline No & Elemen & Material & Variasi desain \\
\hline 1 & Pagar & $\begin{array}{l}\text { - Tembok } \\
\text { - Bambu } \\
\text { - Vegetasi }\end{array}$ & $\begin{array}{l}\text {-Tembok solid } \\
\text { - Vegetasi rapat sebagai pembatas } \\
\text { dan grid dari bambu }\end{array}$ \\
\hline 2 & Gerbang & - Kayu & $\begin{array}{l}\text { - Formal } \\
\text { - Non-formal }\end{array}$ \\
\hline 3 & Jalan Setapak & $\begin{array}{l}\text { - Batu } \\
\text { - Cetakan } \\
\text { Semen }\end{array}$ & $\begin{array}{l}\text { - Modular unit tak teratur } \\
\text { - Modular unit teratur }\end{array}$ \\
\hline 4 & Jembatan & $\begin{array}{l}\text { - Batu } \\
\text { - Kayu }\end{array}$ & $\begin{array}{l}\text { - Batu pipih natural } \\
\text { - Batu pipih dengan polesan halus } \\
\text { - Kayu gelondongan melintang } \\
\text { - Kayu dengan bentuk lengkung busur }\end{array}$ \\
\hline 5 & $\begin{array}{l}\text { Susunan } \\
\text { Bebatuan }\end{array}$ & - Batu & $\begin{array}{l}\text { - Disusun dengan prinsip segitiga } \\
\text { - Diletakkan dengan komposisi dinamis }\end{array}$ \\
\hline 6 & Lentera & - Batu & $\begin{array}{l}\text { - Lentera persegi dengan satu khaki } \\
\text { - Lentera segilima dengan kaki empat } \\
\text { - Lentera dengan polesan kasar }\end{array}$ \\
\hline 7 & Wadah Air & - Batu & $\begin{array}{l}\text { - Wadah dengan desain polesan halus } \\
\text { - Wadah dengan desain bentuk organik } \\
\text { (tak teratur) }\end{array}$ \\
\hline 8 & Pepohonan & $\begin{array}{l}\text { - Pinus } \\
\text { - Azalea } \\
\text { - Lumut } \\
\text { - Pakis }\end{array}$ & $\begin{array}{l}\text { - Pinus terpangkas rapi } \\
\text { - Azalea berbentuk bulat dan lanjong } \\
\text { - Lumut sebagai penutup tanah (ground cover) } \\
\text { - Pakis sebagai tanaman aksen }\end{array}$ \\
\hline 9 & Kolam & $\begin{array}{l}\text { - Air } \\
\text { - Pasir }\end{array}$ & $\begin{array}{l}\text { - Bentuk kolam air selalu organik } \\
\text { - Kolam pasir berbentuk segi empat } \\
\text { - Kolam pasir berbentuk organik }\end{array}$ \\
\hline 10 & Air Terjun & $\begin{array}{l}\text { - Air } \\
\text { - Pasir }\end{array}$ & $\begin{array}{l}\text { - Air terjun tinggi } \\
\text { - Air terjun lebar dengan ketinggian rendah }\end{array}$ \\
\hline
\end{tabular}


Studi eksplorasi kedua menghasilkan konsep taman Jepang menurut pengamat ahli dari Indonesia. Konsep ini dapat dipakai sebagai pedoman mendesain nuansa taman Jepang di Indonesia. Konsep dan alternatif visualisasinya dapat dilihat pada tabel 2 .

Tabel 2. Alternatif Visualisasi Berdasar Tema-tema yang Muncul

\begin{tabular}{|c|c|c|}
\hline No & Tema & Alternatif Visualisasi \\
\hline 1 & Keserasian dengan alam & $\begin{array}{l}\text { Taman yang serasi dengan alam dapat } \\
\text { divisualisasikan dengan memakai vegetasi } \\
\text { seperti Bambu, semak dan pepohonan. } \\
\text { Selain itu pemakaian unsur air juga memberikan } \\
\text { kesan alami dengan cara membuat danau } \\
\text { dan aliran sungai buatan. } \\
\text { Bukit dan gunung tiruan juga merupakan } \\
\text { unsur alam yang biasa ditiru }\end{array}$ \\
\hline 2 & Lingkungan yang terkontrol & $\begin{array}{l}\text { Kontrol lingkungan digambarkan dengan pemberian } \\
\text { batas-batas yang tegas dalam setiap area seperti } \\
\text { pada area pasir dan rumput. } \\
\text { Pemangkasan tanaman dan pembatasan area } \\
\text { taman dengan pelingkup. Pembatasan ini } \\
\text { memberikan kesan alam buatan namun } \\
\text { tidak berkesan kaku dan aneh. }\end{array}$ \\
\hline 3 & Penataan Minimalis & $\begin{array}{l}\text { Penataan minimalis dicapai dengan dua cara } \\
\text { yaitu pemakaian bentuk-bentuk murni } \\
\text { (tanpa penggayaan berlebihan) dan perletakan } \\
\text { elemen yang cenderung soliter. Penataan minimalis } \\
\text { juga dapat dicapai dengan pemakaian hamparan } \\
\text { bidang kosong ( pasir atau rumput ) yang dominan } \\
\text { dengan aksen. elemen-elemen di sekitarnya. } \\
\text { Vegetasi juga dibatasi varietasnya agar tidak } \\
\text { menimbulkan kesan semarak. } \\
\end{array}$ \\
\hline 4 & Kedamaian & $\begin{array}{l}\text { Visualisasi kedamaian dapat tercapai dari penataan } \\
\text { minimalis diatas. Pemakaian bentuk-bentuk murni } \\
\text { yang sederhana memberikan efek ketenangan } \\
\text { dalam suatu desain. }\end{array}$ \\
\hline
\end{tabular}


Selain konsep desain taman, studi eksplorasi awal juga menemukan prinsipprinsip komposisi desain taman Jepang menurut pengamat ahli dari Indonesia. Unsur komposisi dan prinsip dasarnya dapat dilihat pada tabel 3 dibawah ini.

Tabel 3. Prinsip Komposisi Taman Jepang Menurut pengamat dari Indonesia

\begin{tabular}{|c|c|c|c|}
\hline No & Unsur Komposisi & Prinsip & Alustrasi \\
\hline 1. & Keseimbangan & Dinamis \\
\hline 3. & Irama & Terikat \\
\hline 4. & Kesatuan & Organik \\
\hline 5. & Pola & Selaras \\
\hline & Proporsi & Miniatur \\
\hline
\end{tabular}


LINTAS

RUANG | VOL. 1 | EDISI 1 | 2007

ISSN 1978-0702

Sebelum membuat sketsa untuk penelitian utama terlebih dahulu dilakukan rating elemen terhadap sepuluh elemen taman. Rating dilakukan oleh 120 responden

dengan menggunakan skala semantik. Hasil rating tersebut dapat dilihat dalam tabel 4 berikut ini

Tabel 4. Kategorisasi elemen berdasar rating seluruh kelompok

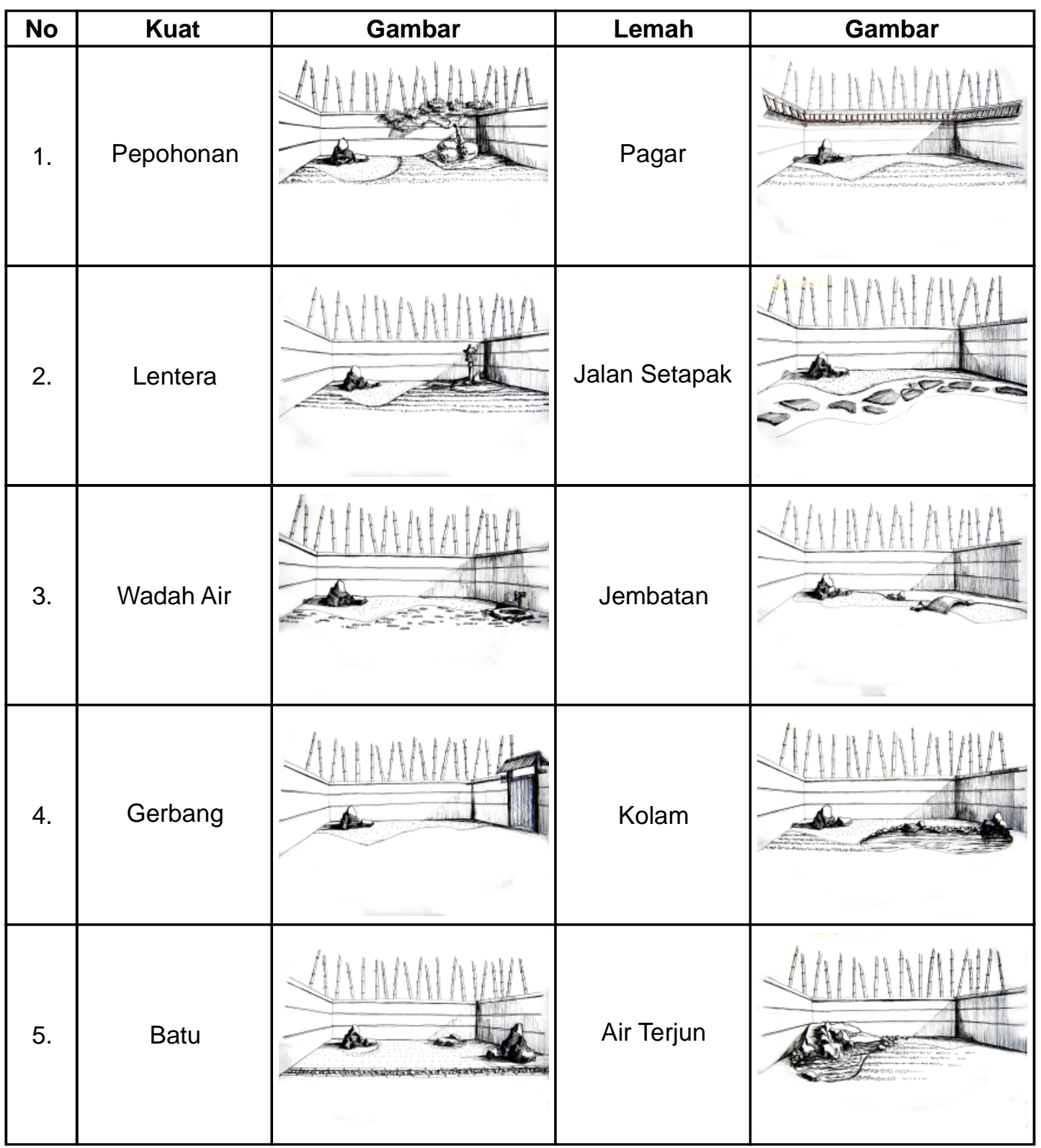


Elemen-elemen yang dinilai kuat mewakili identitas Jepang adalah pepohonan, lentera, wadah air, gerbang dan batu. Elemen-elemen yang dinilai lemah identitas Jepangnya adalah pagar, jalan setapak, jembatan, kolam dan air terjun. Masing masing kategori kemudian disatukan dalam satu komposisi taman dan dipresentasikan kepada 200 responden dalam dua kelompok terpisah yang masing-masing terdiri dari 100 responden. Hasil pengenalan identitas taman masing-masing kelompok dapat dilihat pada tabel 5 dibawah ini.

Tabel 5. Sebaran Jawaban Responden

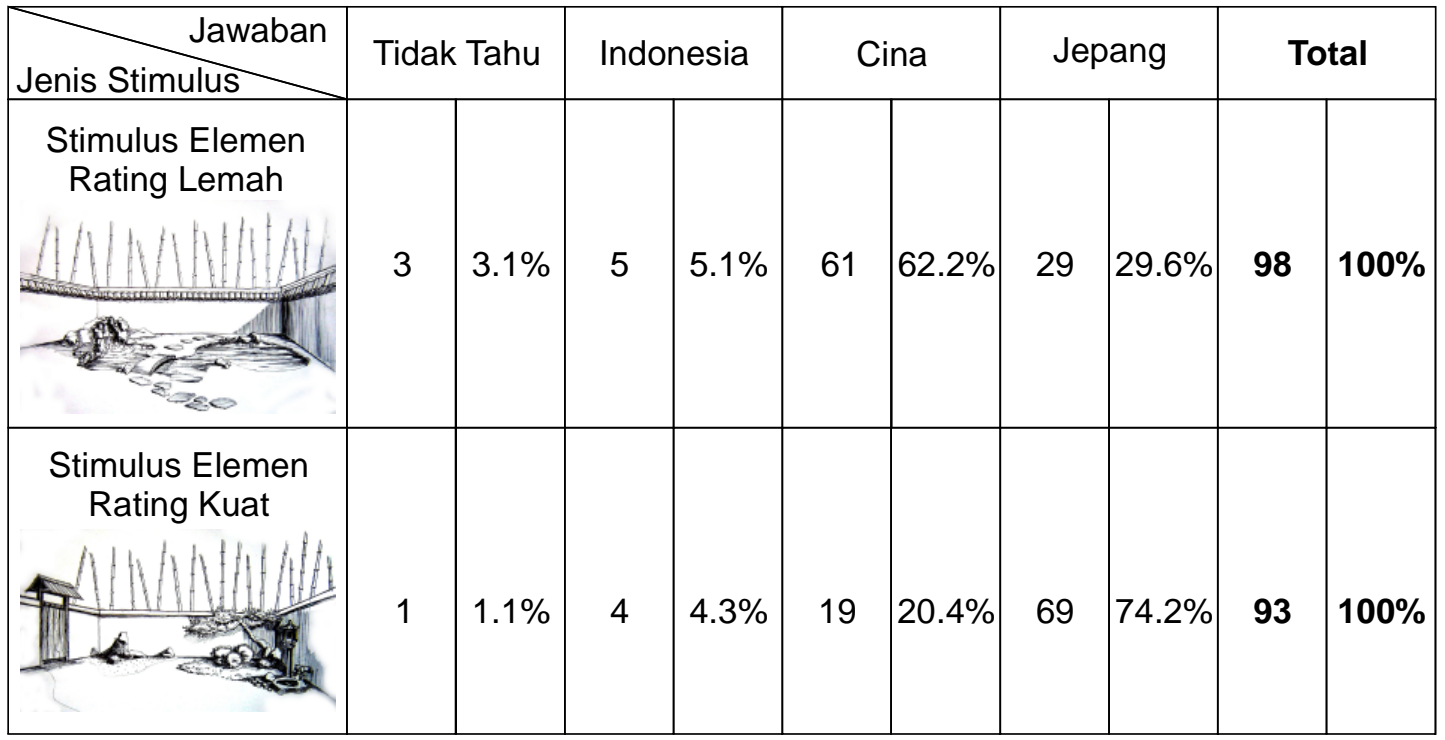

Hasil diatas menunjukkan bahwa stimulus dengan desain elemen rating kuat dikenali sebagai taman Jepang oleh $74,2 \%$ responden. Hal ini menunjukkan bahwa elemen-elemen kuat lebih mudah dikenali oleh pengamat dibandingkan dengan stimulus desain elemen rating lemah. Kelompok subjek dengan stimulus desain elemen rating lemah lebih banyak mengenali taman tersebut sebagai taman Cina $(62,2 \%)$.

Hasil skoring kedua kelompok subjek dapat dilihat pada tabel 6 dibawah ini.

Tabel 6. Perbedaan Mean dan skor Dua Kelompok Subjek

\begin{tabular}{|c|c|c|}
\hline No & Jenis Stimulus & Skor Identifikasi Indentitas Taman \\
\hline 1. & Rating Lemah & $\begin{aligned} & 214 \\
\text { Mean }= & \mathbf{2 , 1 8}(\mathrm{n}=98)\end{aligned}$ \\
\hline 2. & Rating Kuat & $\begin{array}{c}249 \\
\text { Mean=2,68 }(n=93)\end{array}$ \\
\hline
\end{tabular}


RUNTS

ISSN 1978-0702

Tabel 7. Hasil Analisis uji-t

\begin{tabular}{|c|c|c|c|c|c|c|}
\hline \multicolumn{2}{|c|}{ Levene's Test for Equality of Variances } & \multicolumn{4}{|c|}{$t$-test for Equality of Means } \\
\hline & $\mathrm{F}$ & Sig. & $\mathrm{t}$ & $\mathrm{df}$ & $\begin{array}{c}\text { Sig. } \\
\text { (2-tailed) }\end{array}$ & $\begin{array}{c}\text { Mean } \\
\text { Difference }\end{array}$ \\
\hline Equal variances assumed & .005 & .941 & -5.343 & 189 & .000 & -.49 \\
\hline Equal variances not assumed & & & -5.355 & 188.83 & .000 & -.49 \\
\hline
\end{tabular}

Pengujian untuk menentukan adanya perbedaan yang sigifikan diantara kedua nilai mean tersebut dilakukan dengan analisis Ujit. dengan taraf signifikansi $0,05(p=0,05)$ Hasilnya dapat dilihat pada tabel 7.

Hasil analisis uji-t menunjukkan nilai signifikansi $0,000 \quad(p<0,05)$ hal ini menunjukkan bahwa stimulus dengan elemen rating kuat dan stimulus elemen dengan rating lemah berbeda secara signifikan pada tingkat pengenalan identitas taman. Stimulus elemen rating kuat memiliki tingkat akurasi pengenalan sebagai taman Jepang lebih tinggi dibandingkan dengan stimulus elemen rating lemah.

Hasil ini membuktikan dugaan awal dalam penelitian yang menyatakan terdapat perbedaan pengaruh elemen penanda pada pengenalan identitas taman Jepang oleh pengamat dari Indonesia.

Hasil rating elemen yang dilakukan untuk menjawab pertanyaan penelitian elemen apa saja yang memiliki asosiasi kuat dan lemah menunjukkan bahwa elemen pepohonan, lentera, wadah air, gerbang dan batu memiliki asosiasi kuat terhadap identitas Jepang. Elemen yang memiliki asosiasi lemah adalah jalan setapak, kolam, air terjun, jembatan dan pagar.

Hasil penelitian juga mengungkapkan bahwa elemen-elemen dalam taman Jepang dipersepsi secara bertingkat oleh pengamat dari Indonesia. Tingkat terlemah dari elemen taman Jepang adalah air terjun sedangkan tingkat terkuat adalah pepohonan yang berbentuk pohon Pinus bonsai dan semaksemak terpangkas bundar. Hasil ini sejalan dengan temuan pada studi eksplorasi kelompok ahli yang menyatakan bahwa taman Japang adalah lingkungan dengan kontrol manusia. Pinus dan semak yang di pangkas rapi merupakan ciri terkuat dari konsep kontrol terhadap alam.

Berdasarkan hasil uji statistik menunjukkan nilai signifikansi 0,000 dengan nilai $p<0,05$ sehingga dapat disimpulkan bahwa desain taman Jepang dengan elemen-elemen kuat terbukti lebih mudah dikenali dibandingkan dengan desain dengan elemen penada lemah.

Studi eksplorasi yang dilakukan dalam penelitian awal juga mengungkapkan beberapa prinsip komposisi taman Jepang menurut pengamat ahli. Prinsip komposisi ini antara lain keseimbangan a simetris, irama yang dinamis, kesatuan yang dicapai dengan pengikatan, pola desain organik dan proporsi elemen yang selaras.

Perancang taman Jepang yang bermaksud membangun taman Jepang di Indonesia dapat mempergunakan elemenelemen seperti pohon Pinus terpangkas, semak-semak budar, lentera, wadah air dengan pancuran serta gerbang sebagai penguat Identitas Jepang. Penguatan ini harus diimbangi dengan penggunaan elemen pembatas (enclosure) dan prinsip-prinsip dasar yang terdapat dalam taman Jepang.

Penelitian mengenai pengaruh elemen penanda pada pengenalan identitas lingkungan ini memberi gambaran tentang elemen-elemen apa saja yang dengan mudah dapat digunakan sebagai petunjuk pengenalan identitas lingkungan. Banyak hal yang masih bisa dikembangkan dari penelitian ini diantaranya:

1. Penggalian nilai (value) yang terdapat pada taman Jepang bagi masyarakat Indonesia belum terungkap dalam penelitian ini. Kelima elemen taman yang dinilai kuat dalam penelitian ini merupakan persepsi visual masyarakat Indonesia terhadap taman Jepang. Penelitian selanjutnya diharapkan mampu mengungkapkan mengapa elemen-elemen tersebut memiliki identitas kuat dan makna apa yang ditangkap oleh masyarakat Indonesia 
2. Penelitian selanjutnya juga dapat dilakukan dengan merubah kombinasi tiap elemen dengan variasi yang berbeda untuk mengetahui apakah perubahan variasi tersebut berpengaruh pada identitas taman Jepang. Variasi ini berhubungan dengan pengaturan komposisi taman sehingga penelitian lanjutan juga dapat mengungkapkan apakah komposisi taman yang berbeda mempengaruhi kuat-lemah identitas Jepang.

\section{DAFTAR PUSTAKA}

Bell A, Paul. 1996. Environmental Psychology. New York: Harcourt Brace Collage Publishers.

Bring, Mitchell and Wayamberg, Josse. 1981. Japanese Garden. Design and Meaning. Tokyo: Mc Graw Hill Book Company

Burns, Robert B. 2000. Introduction To Research Methods. London :Sage Publications

Hornby, A.S. 1987. Oxford Advanced Learner's Dictionary Of Current English. Oxford: Oxford University Press.

Keane, Marc P. 1996. Japanese Garden Design. Tokyo: Charles E. Tuttle Company.

Nyunt, Koung. 1978. Study On Japanese Traditional Living Space and Landscaping. Rangoon: Dept. Of Architecture Rangoon Institute Of Technology.

Pile, John. F. 1995. Interior Design. New York: Harry N. Abrams, Inc., Publishers.

Rapoport, Amos. 1982. The Meaning Of The Built Environment. Baverly Hills: Sage Publication.
Sanoff, Henry. 1991. Visual Research Methods In Design. New York: Van Nostrand Reinhold.

Veitch, Russel dan Arkellin,Daniel.1995 Environmental Psychology. an interdisciplinary perspective. New Jersey: Prentice-Hall,Inc. 